\title{
Oil Price Shocks and Macroeconomic Dynamics in an Oil-Exporting Emerging Economy: A New Keynesian DSGE Approach
}

\section{Sunday Oladunni ${ }^{1}$}

The global oil dynamics has significant implications for both oil exporting and importing small open economies. However, much of the literature on oil shocks is oriented towards advanced oil-importing economies. Micro-founded studies that explore the effects of oil shocks from the standpoint of oil-endowed emerging economies are rather sparse, compared to the preponderance of studies on developed oil importers and exporters. Thus, resulting to a consequential knowledge gap on oil price transmission mechanism and a limited appreciation of the growing policy dilemmas in these economies. The paper, therefore, sets up a new Keynesian dynamic stochastic general equilibrium (DSGE) model to study how an oil price shock impact macroeconomic aggregates in an oil-rich emerging economy. We consider a positive oil price shock to uncover the extent to which oil price increase is positive for the economy. The typical small open economy model is enriched with an export-oriented oil firm, a multi-sector foreign production and a non-oil domestic firm. The model is closed with exchange rate-augmented interest rate rule, and it is calibrated for Nigeria, an important oil producer. Macroeconomic responses, sequel to a simulated positive oil price shock, reveal evidence of Dutch disease and the operation of the Harrod-Balassa-Samuelson effect. We find a compelling need for oil-endowed emerging economies to address these phenomena by ensuring a robust non-oil sector with limited exposure to the vagaries of oil price oscillation.

Keywords: DSGE Model, Emerging Oil Exporter, Macroeconomic Dynamics, Oil Price

JEL Classification: E32, F41, F47, Q41

DOI: $10.33429 /$ Cjas.11120.1/5

\section{Introduction}

The recurrent episodes of oil price shocks have direct bearing on macroeconomic conditions in both oil exporting and importing economies. There is an ongoing debate on the relative impact of positive and negative oil price shocks among oil importers and exporters. Policymakers in both climes are equally keen to understand oil shocks' main transmission channels and the appropriate policy tools for achieving optimal response in the event of such

\footnotetext{
${ }^{1}$ The author is a staff of Monetary Policy Department of the Central Bank Nigeria.

The views expressed in this paper are solely those of the author and do not necessarily represent those of the Central Bank of Nigeria.
} 
Oil Price Shocks and Macroeconomic Dynamics in an Oil-Exporting Emerging Economy: A New Keynesian DSGE Approach

shocks. However, the literature is dominated by discourse on the evolution of oil price shocks, their distortionary effects and the consequent role of monetary policy in oil-importing advanced economies. The effect of oil shocks on oil exporting emerging economies is less explored and thus, pertinent questions on oil shocks and business cycle dynamics in these economies have only provoked unsatisfactory, limited and inconclusive answers. Also, despite a preponderance of literature on advanced oil importers, only a tiny fraction employ micro-founded models to analyse this phenomenon; and much few focus on oil exporting emerging economies.

Macroeconomic conditions in emerging oil exporters tend to move in tandem with oil price evolution, introducing a revolving cycle of boom and burst. Oil-dependent economies come under pressure whenever the price of oil plummets and they reap windfalls when oil prices rise. Whereas the negative effect of sustained drop in oil prices is easily seen through worsening macroeconomic performance, the effect of higher oil prices remains open to debate in these economies. The Dutch disease and resource curse syndromes are commonplace in several resource-rich economies, thus making the question about the exact long-run effects of increase in commodity prices on resource endowed emerging economies a pertinent one (Otaha, 2012). Vulnerabilities in these economies tend to undermine the potential long-term benefits of increases in oil price. Consequently, in this paper, we seek to embed oil in the typical Gali and Monacelli (2005) model for an emerging oil producer and to examine the effect of a positive oil price shock on the model economy. Our model enriches the oil-exporting emerging economy's DSGE literature and allows us to extract crucial policy insights following the analysis of the dynamic macroeconomic responses to a positive oil price shock.

Since Gali and Monacelli (2005) sets out the micro-founded general equilibrium framework for modelling small open economies, with a role for the exchange rate, there has been a growing appetite in the literature to embed commodity dynamics in small open economies dynamic stochastic general equilibrium (DSGE) models. Within the context of an oil importer, Leduc and Sill (2004) simulated a dynamic stochastic general equilibrium (DSGE) model and reports that, although policy makers cannot totally insulate their economies from oil-price shocks induced consequences, their response to the shock is crucial in determining how profoundly the shock will impact their economies. They show that a response via interest rate increase may amplify the effect of an oil shock on output, while an easy monetary 
policy through money growth may help contain the size of the impact. Medina and Soto (2005) incorporate oil in dynamic stochastic general equilibrium (DSGE) model estimated for Chile and finds that a positive real oil price shock induced output contraction and inflationary pressure; and that, the monetary policy rule that responds to wage rigidity is next to the second best outcome; while indicating that a full inflation stabilization policy response from the central bank is at a considerable output cost.

Romero (2008) modelled an oil producing economy in a two-sector DSGE model featuring a representative oil firm and an oil-utilizing final goods firm and showed that that oil price shock tends to exacerbate inflation pressures, resulting from the standard cost-push effect and a marginal cost perturbing wealth effect. In addition, he finds that the simple policy rule that responds to consumption is welfare superior. Ferrero and Seneca (2019) constructed a DSGE model for Norway with a modelling framework that accommodates linkages and spill overs between the oil producing sector and the rest of the economy; and a fiscal policy rule that allows for a sovereign wealth fund for warehousing oil receipts. They suggest that the central bank should respond to a negative oil price shock by reducing interest rate and indicated that domestic inflation stabilization is the welfare-consistent policy rule.

A few studies on Middle East and North Africa (MENA) countries have shed light on the dynamic interactions between oil price shocks and macroeconomic dynamics in the region. For instance, in a stylized DSGE model estimated for Algeria, Allegret and Benkhodja (2015) used pricing rule for imported refined oil to capture foreign oil price pass-through. Their result indicates that in the presence of oil price shock, targeting core inflation provides the best outcome for economic stabilization and social welfare in Algeria. Meanwhile, in an earlier study on Algeria, Benkhodja (2014) recommends inflation targeting under a flexible exchange rate system as the most appropriate way to insulate an oil exporting economy from the Dutch disease. In addition, Omran, Ehsani and Khyareh (2015) follows Romero (2008) to model oil as a productive factor in the non-oil sector for Iran. They identify multiple shocks and report that domestic inflation targeting rule is welfare superior given a productivity shock, while the exchange rate targeting rule maximizes welfare.

Hove, Mama and Tchana (2015) evaluates alternative monetary policy setups given terms of trade shock in a multi-sector commodity exporting small open economy (SOE) DSGE model calibrated for South Africa. Their framework explores production in the foreign economy 
Oil Price Shocks and Macroeconomic Dynamics in an Oil-Exporting Emerging Economy: A New Keynesian DSGE Approach

and reflects the small open economy's commodity export in the foreign economy's production dynamics. Their findings suggest that, in the event of a shock to the terms of trade, the CPI targeting monetary policy rule will produce the highest support for macroeconomic stabilization and welfare, though at a cost of high exchange rate volatility. More recently, Algozhina (2016) in a SOE DSGE model with monetary and fiscal instruments, multi-sector production, heterogeneous households and fiscal savings, allows for foreign exchange reserves in the uncovered interest rate parity (UIP) equation and finds that given a negative oil price shock, a pro-cyclical fiscal policy stance can be combined with a CPI inflation targeting monetary rule in a flexible exchange rate environment to achieve the optimum welfare outcomes.

Despite Nigeria's status as the largest economy in Africa and a major oil exporter, the DSGE literature on the economy is rather sparse; with only a handful providing inconclusive insights on external shocks and macroeconomic responses. Olekah and Oyaromade (2007) specified a small scale open economy DSGE model based on Lubik and Schorfheide (2005) and Fukač and Pagan (2010) but only performed a pseudo-estimation using the vector-autoregressive (VAR) technique and reports that inflation is sensitive mainly to output changes and that interest rate volatility is traceable to exchange rate and inflation shocks in Nigeria. Alege (2008) incorporates an export sector into Nason and Cogley (1994), and Schorfheide (2000) to estimate a model to characterize the Nigerian business cycle and finds that technology, monetary and export shocks has effects on the Nigerian business cycle and that the link between the macro economy and the external sector is weak. Olayeni (2009) using a Bayesian DSGE-VAR approach, analyses monetary policy shocks under four alternative formulations and finds that the monetary authority in Nigeria is business cycle-conscious. Estimation results from the study suggests that the policy maker's benign response to exchange rate fluctuations account for the observed exchange rate overshooting and persistence. Thus, the paper recommends that monetary policy should reflect strong inertia and be more aggressive towards the exchange rate. Adebiyi and Mordi (2012) estimates a DSGE model to examine the pass-through from exchange rate and oil price to domestic economy and finds evidence in support of a small and incomplete exchange rate pass-through to domestic inflation while their findings on exchange rate response to oil price shock is rather less definitive as it was negative on impact and then turned positive in the third quarter with an extended period of 
persistence. Iklaga (2017) in a Smets and Wouters (2003)-type model modified for Nigeria, finds that a positive oil price shock elicits exchange rate appreciation, consumption increase, aggregate output and employment contraction. In the same vein, the optimized monetary policy rule that targets real wage is reported to be superior, albeit, at a cost of high interest rate volatility.

Rasaki (2017) employ the Bayesian technique to estimate a small open economy DSGE model for Nigeria, which embeds a non-separable money in the utility function following Andrés, David and Vallés (2006), to allow monetary aggregate an active role in the economy. Their results suggest that inflation in Nigeria is a monetary phenomenon, price stickiness is observed, and monetary policy reacts to exchange rate movement; while foreign inflation, external debt and exchange rate shocks are shown to drive output in Nigeria. More recently, Omotosho (2019) in an estimated new Keynesian DSGE model which features oil price passthrough and fuel subsidies, reports that a negative oil price shock reduces aggregate output, catalyses non-oil output, increases inflation and depreciates the exchange rate. The paper further shows that the severity of output contraction sequel to a negative oil price shock is amplified in a model with fuel subsidies but advise caution on the removal of fuel subsidies due to observed amplification of macroeconomic volatilities, resulting therefrom. Omotosho (2019), however, is silent about the phenomena of Dutch disease and the Harrod-BalassaSamuelson Hypothesis. The effects of these, when found to be operational in a commodityendowed economy, tend to diminish the impact of a positive commodity price shock.

Although, some studies suggest that oil price is a prime driver of the Nigerian business cycle (Akpan, 2009; Kilishi, 2010; Oladunni, 2019); however, the literature on the pattern of interactions between oil price shock and business cycle variables in Nigeria is too limited to allow for a meaningful consensus for policy purposes. Policymakers require a robust understanding of the dynamic interactions between oil price movements and macroeconomic aggregates for macroeconomic diagnostics and policy purposes. The interaction should not be obscure to policy makers, especially in economies with inherent external sector vulnerabilities. Specifically, the study seeks to establish the impact positive oil price shocks relating to Dutch disease in the economy. Therefore, we leverage Gali and Monacelli (2005) and Hove et al. (2015) to construct a multi-sector new Keynesian small open economy DSGE model that feature, explicitly, an oil sector and simulate an oil price shock. We analyse macroeconomic 
Oil Price Shocks and Macroeconomic Dynamics in an Oil-Exporting Emerging Economy: A New Keynesian DSGE Approach

responses sequel to a positive oil price shock. The SOE model of Gali and Monacelli (2005) has become the benchmark model for studying fundamental features of SOEs and monetary policy options for welfare maximization. Given key SOE's model building blocks, we added oil and foreign production sectors to highlight the interaction between the SOE and the foreign economy production sectors, a strategy that ensures SOE's oil export feature in foreign production as input.

The model is calibrated to capture some broad features of oil producing emerging economies and it is simulated with a positive oil price shock under alternative monetary policy rule specifications. Consequently, we find evidence of Dutch disease in the economy. Both the non-tradable and total output contracted in response to a positive oil price shock, and this is most amplified under the CPI targeting monetary rule. The significant increase in oil output somewhat offsets the decline in non-oil output leading to higher employment and consumption. The exchange rate is associated with a marked appreciation while the inflation threat was benign on impact, but later became manifest. The monetary authority lowered the interest rate in response to the Dutch disease. The article is structured as follows. Section 1 introduces the paper while section 2 discusses the model in detail. Section 3 explores model calibration, solution and simulation, while in section 4, we analyse the results and section 5 concludes the paper.

\section{The Model}

\subsection{Model Outline}

We model a two-sector small open economy endowed with an oil resource as shown in figure 1 below. There is a representative household, which consumes both foreign and domestic goods, two classes of representative firms; one producing non-traded goods and the other producing oil exclusively for export. There is a central bank that cares about private agents' welfare and implements monetary policy to achieve this objective. The domestic economy interacts with the rest of the world (ROW) via export of oil to and import of consumption goods from the ROW. The oil producing firm operates in a perfectly competitive market while the non-tradable goods producing firm operates as a monopolistic competitor.

The inclusion of an oil sector in the model enriches the original Gali and Monacelli (2005)type of small open economy new Keynesian DSGE models and allows for the exploration of 
possible interactions between the oil export-oriented sector and the wider domestic economy. A two-sector model can provide better understanding of the nature and variety of shocks policy makers should anticipate and the appropriate response whenever these shocks hit the economy. This is crucial in the light of the fact that macroeconomic fundamentals in oil exporting economies are largely driven by demand and supply dynamics in the oil market.

The model features price stickiness in line with Calvo (1983) in the domestic (non-tradable goods) sector; thus, allowing for inflation and a role for monetary policy. In the tradable sector, the law of one price holds, thus there is no separate Philip's curve for imports, although the general price index still captures imported component of inflation. Also, a complete assets market is assumed, hence there are no financial frictions in the model. It also features complete exchange rate pass-through to domestic prices for imported goods. The pricing system for the oil firm is such that it is a price taker in a dollar pricing world. Therefore, oil price is taken as given and typically, the firm makes a zero profit.

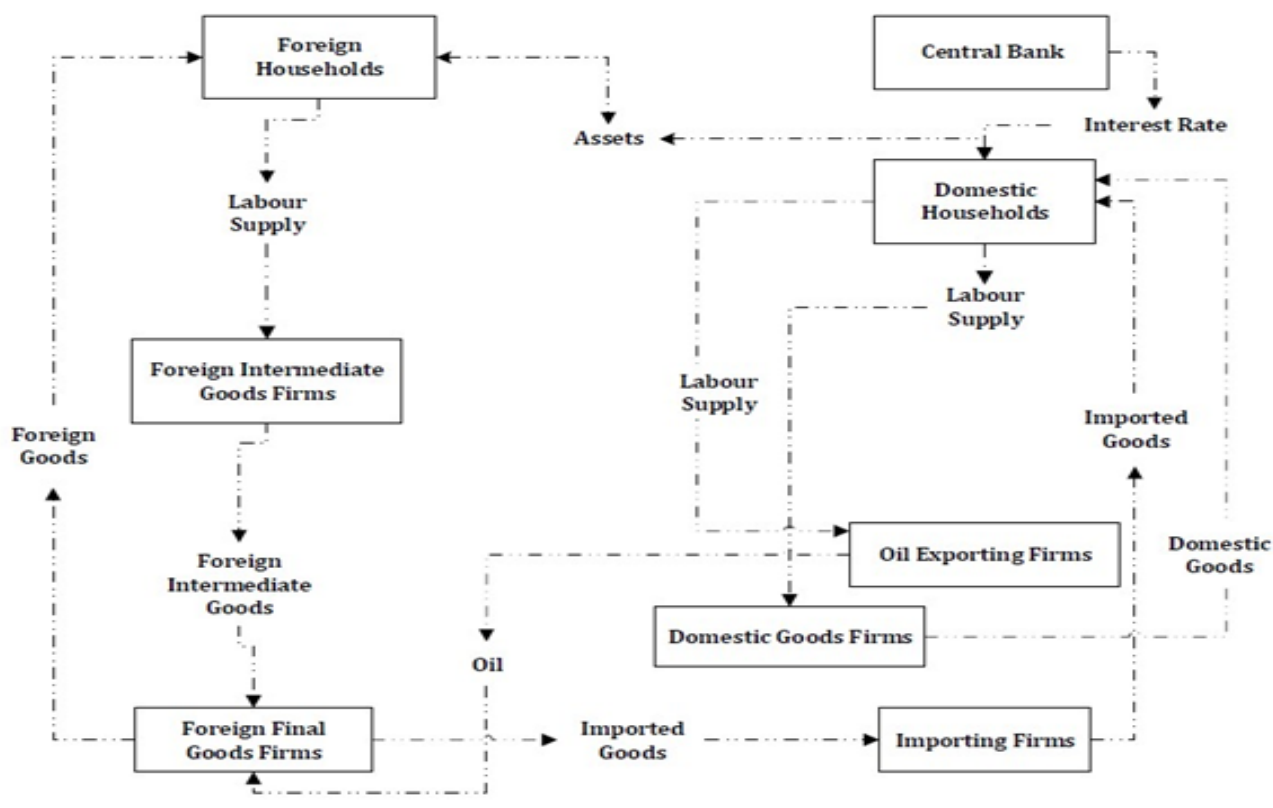

Figure 1: Overview of Model

Capital and investment do not feature in the model in line with argument by McCallum and Nelson (1999) that, for a small open economy, the stock of capital is inconsequential 
Oil Price Shocks and Macroeconomic Dynamics in an Oil-Exporting Emerging Economy: A New Keynesian DSGE Approach

for the economy's dynamics since the contribution of capital changes to the business cycle fluctuations is small. In line with the Gali and Monacelli (2005) tradition, firm's production function incorporates only labour input; except for the foreign final goods firm that utilizes oil and foreign intermediate goods as inputs. Households enjoy domestic firm's ownership for profits and supply labour to both domestic and oil firms for wages. Labour is perfectly mobile across all sectors. Monetary policy is modelled using a typical Taylor rule, augmented with the exchange rate and a smoothing parameter.

\subsection{Household}

We model an economy populated by an infinite number of atomistic, but identical households. Thus, a representative household approximates preferences of all households with respect to consumption and hours of work. The representative household seeks to maximize utility, given an inter-temporal budget constraint. The utility function is of the form:

$$
\begin{aligned}
& V=E_{0} \sum_{t=0}^{\infty} \beta^{t} U_{t}\left(C_{t}, L_{t}\right) \\
& U_{t}(.)=\frac{C_{t}^{1-\eta}}{1-\eta}-\frac{L_{t}^{1+\varrho}}{1+\varrho}
\end{aligned}
$$

Where $\beta^{t}$ is the discount factor, $C_{t}$ is a composite index of consumption goods, $\mathrm{L}_{t}$ are hours of work; $\eta$ is the relative risk aversion coefficient, otherwise referred to as the inverse of the elasticity of inter-temporal substitution, and $\varrho$ is the elasticity of the marginal dis-utility of labour. Both $\eta$ and $\varrho$ take, strictly, positive values.

The household's composite consumption $C_{t}$ includes non-tradable (domestic) good $C_{t}^{h}$, and imported good, $C_{t}^{f}$. Using the Dixit and Stiglitz (1977) aggregator, the composite consumption for the economy is expressed as:

$$
C_{t}=\left[(\psi)^{\frac{1}{v}}\left(C_{t}^{h}\right)^{\frac{v-1}{v}}+(1-\psi)^{\frac{1}{v}}\left(C_{t}^{f}\right)^{\frac{v-1}{v}}\right]^{\frac{v}{v-1}}
$$

where the parameter $\psi$ represents the weight or share of domestically produced, non-tradable goods in total consumption, which may be interpreted as the "home bias" coefficient; while $1-\psi$ is the weight of foreign goods in total consumption, which denotes the import share in total domestic consumption and could be termed as the degree of openness index for this economy. The parameter $v>0$ is the elasticity of substitution between domestically produced non-tradable goods $C_{t}^{h}$ and imported goods $C_{t}^{f}$. It depicts the consumer's taste for 
variety. Consumption of non-tradable and imported goods are defined as follows, using the constant elasticity of substitution (CES) aggregators:

$$
C_{t}^{h}=\left(\int_{0}^{1} C_{t}^{h}(i)^{\frac{v-1}{v}} d i\right)^{\frac{v}{v-1}}, C_{t}^{f}=\left(\int_{0}^{1} C_{t}^{f}(i)^{\frac{v-1}{v}} d i\right)^{\frac{v}{v-1}}
$$

where $C_{t}^{h}(i)$ and $C_{t}^{f}(i)$ denotes consumption of home and foreign goods of variety $(i)$ by the representative household. The parameter $v>1$ is the elasticity of substitution within each goods category.

Household optimal consumption allocation can be obtained by minimizing expenditures relating to each good category subject to their respective CES consumption aggregators. When total consumption cost is minimized subject to the composite consumption index, the optimal household expenditure allocation, reflecting the weights of non-tradables and imports in the entire consumption basket, respectively will yield the following demand functions:

$$
C_{t}^{f}=\psi\left(\frac{P_{t}^{h}}{P_{t}}\right)^{-v} C_{t}, C_{t}^{f}=(1-\psi)\left(\frac{P_{t}^{f}}{P_{t}}\right)^{-v} C_{t}
$$

The overall consumer price index, $P_{t}$ is defined as:

$$
P_{t}=\left[\psi\left(P_{t}^{h}\right)^{1-v}+(1-\psi)\left(P_{t}^{f}\right)^{1-v}\right]^{\frac{1}{1-v}}
$$

Consequently, the small open economy's household minimum total consumption expenditures will be:

$$
P_{t}^{h} C_{t}^{h}+P_{t}^{f} C_{t}^{f}=P_{t} C_{t}
$$

Performing a log-transformation on (6) we obtain a Consumer Price Index (CPI) in the CobbDouglas functional form as follows:

$$
P_{t}=P_{t}^{h(\psi)} P_{t}^{f(1-\psi)}
$$

Where $\psi$ and $1-\psi$ are weights associated with non-tradable and imported goods, respectively, in the overall domestic consumer price index. The representative household's intertemporal budget constraint can be expressed as follows:

$$
P_{t} C_{t}+T^{l}+E_{t}\left(\xi_{t+1} B_{t+1}\right) \leq W_{t} L_{t}+B_{t}+\Pi_{t}
$$


Oil Price Shocks and Macroeconomic Dynamics in an Oil-Exporting Emerging Economy: A New Keynesian DSGE Approach

where $P_{t} C_{t}$ is the consumer's minimum total consumption expenditure, $\mathrm{W}_{\mathrm{t}}$ is the wage rate, $B_{t}$ is one period asset portfolio $B_{t+1}$ is the nominal pay-off of period $\mathrm{t}+1$ from asset portfolio held at the end of period t. $E_{t}\left(\xi_{t+1}\right)$ is defined as $R_{t}^{-1}$ and it is the stochastic discount factor, $R_{t}$ is the domestic interest rate, $T^{l}$ is lump-sum tax and $\Pi_{t}$ is profits transferred to household by the domestic monopolistically competitive firms. Labour wage is assumed to be the same in all sectors, and it is taken as given by the household. The representative household decides on consumption, labour and assets holding to maximize welfare (utility) subject to the prevailing inter-temporal budget constraint.

Given the household budget constraint, the general set up of the household problem becomes:

$$
\mathscr{L}=\sum_{t=0}^{\infty} \beta^{l} U\left(C_{t}, L_{t}\right)-\lambda_{t}\left[P_{t}, C_{t}+E_{t}\left(\xi_{t+1} B_{t+1}\right)+T_{t}^{l}-W_{t} L_{t}-B_{t}-\Pi_{t}\right]
$$

where $\lambda_{t}$ is the Lagrangian multiplier capturing the marginal utility of wealth. The first order conditions (FOCs) of 10 with respect to consumption $C_{t}$, labour supply (hours of work) $L_{t}$ and household's portfolio of assets $B_{t}$, are obtained as follows:

$$
\begin{aligned}
& C_{t}^{-\eta}=\lambda_{t} P_{t} \\
& L_{t}^{\rho}=\lambda_{t} W_{t} \\
& \lambda_{t}=\beta E_{t} \lambda_{t+1} R_{t}^{-1}
\end{aligned}
$$

From equations (11) and (12), we obtain the following equation:

$$
C_{t}^{\eta} L_{t}^{\rho}=\frac{W_{t}}{P_{t}}
$$

Equation (14) is the labour supply equation, an expression which equates the marginal value of labour to the marginal utility of consumption. It states that the relative price (real wage) of consumption-leisure should be equal to the marginal rate of substitution of leisure-consumption. It implies that higher consumption is only possible if there is an increase in labour hours. To consume more, the household must forfeit some leisure to work and earn more. This underscores the trade-off between leisure and consumption. Consumption can also increase if the real wage rises while the consumer enjoys the same level of leisure. 
Equation (15) below is the Consumption Euler equation, which reflects the trade-off associated with the inter-temporal allocation of the household consumption and it is obtained by re-arranging equation 13 , and substituting $\lambda_{t}$ and $\lambda_{t-1}$ respectively.

$$
1=\beta R_{t} E_{t}\left[\left(\frac{C_{t+1}}{C_{t}}\right)^{-\eta}\left(\frac{P_{t}}{P_{t+1}}\right)\right]
$$

In equation $15,1 / R_{t}$ is the price of a one-period domestic currency denominated bond. $R_{t}$ represents the gross interest rate on the bond. The consumption Euler equation underscores how interest rate influences the household decision whether to consume more or less inter-temporally. The consumer compares the utility derivable from consuming an additional amount now $(t)$ with the utility expected from consuming more in future $(t+1)$. In an environment where interest rate is expected to rise in future, consuming more today will be costly, hence, the willingness to wait and consume more in future.

\subsection{Domestic Firms Production}

The economy is populated by two types of firms engaged in production activity. The first representative firm produces $^{2}$. oil entirely for export to the rest of the world (ROW) and the second firm is engaged in the production of non-tradable final goods. One firm operates in the export (tradable) sector while the other operates in the non-tradable sector. Activity relating to the firm in the non-tradable sector is denoted with the superscript (h) while that relating to the firm in the tradable sector is denoted with the superscript (o). A third class of non-producing firms exist in the economy, they deal in the importation of goods from the foreign economy for domestic consumption.

\subsubsection{Oil Firm}

The representative oil firm is assumed to operate in a perfectly competitive international oil market. The firm employs only labour and its production function evolves linearly as follows:

$$
Y_{t}^{o}=Z_{t}^{o} L_{t}^{o}
$$

Where $Y_{t}^{o}, Z_{t}^{o}$ and $L_{t}^{o}$ is oil output, oil sector productivity variable and labour employed in the oil sector, respectively. The oil firm minimizes cost subject to total output constraint, thus

\footnotetext{
${ }^{2}$ Production here refers to mining of oil minerals from under the ground and beneath the sea for exports
} 
Oil Price Shocks and Macroeconomic Dynamics in an Oil-Exporting

leading to the oil sector real marginal cost function as follows:

$$
R M C_{t}^{o}=\frac{W_{t}}{Z_{t}^{o} P_{t}^{o}}
$$

The equation for the oil sector's real marginal $\operatorname{cost}\left(\mathrm{RM} C_{t}^{o}\right)$ in (24) represents the firm's cost minimizing decision and can be expressed log-linearly as follows:

Given the perfect competition in the oil sector, we can derive the representative oil firm's price as:

$$
P_{t}^{o}=N M C_{t}^{o}=\frac{W_{t}}{Z_{t}^{o}}
$$

We can also, from equation (18) obtain $W_{t}=Z_{t}^{o} P^{o}$; where $N M C_{t}^{o}$ and $R M C_{t}^{o}$ in equations 17 and 18 refer to the nominal and real marginal costs in the oil sector, respectively; and $W_{t}$ is the wage rate, while $P_{t}^{o}$ is the domestic price of oil.

$$
W_{t}=P_{t}^{o} Z_{t}^{o}
$$

\subsubsection{Non-oil Firm}

In the non-oil sector, an imperfectly competitive firm produce differentiated commodities entirely for domestic consumption. Hence, these goods are non-tradable. The non-tradable goods firms are subject to monopolistic competition and they utilize a linear production function as follows:

$$
Y_{t}^{h}=Z_{t}^{h} L_{t}^{h}
$$

where $Y_{t}^{h}$ is the non-tradable goods output, $Z_{t}^{h}$ is non-tradable sector productivity variable and $L_{t}^{h}$ is the employment in the non-tradable sector. The firm's optimality condition resulting from cost minimization process in the non-tradable sector is as follows:

$$
R M C_{t}^{h}=\frac{W_{t}}{Z_{t}^{h} P_{t}^{h}}
$$

Where $\mathrm{RMC} C_{t}^{h}$ is the non-tradable sector's real marginal cost and $P_{t}^{h}$ is the non-tradable good's price. From (21), we can obtain:

$$
P_{t}^{h}=\frac{W_{t}}{Z_{t}^{h} R M C_{t}^{h}}
$$

From (18), we obtain the expression:

$$
W_{t}=Z_{t}^{o} P_{t}^{o}
$$


Similarly, from (22) we derive:

$$
W_{t}=P_{t}^{h} Z_{t}^{h} R M C_{t}^{h}
$$

Assuming wage equalization in the tradable and non-tradable production sectors, equations 23 and 24 can be used to derive the relative price of non-tradable goods to oil as follows:

$$
P_{t}^{h}=\frac{Z_{t}^{o}}{Z_{t}^{h} R M C_{t}^{h}} P_{t}^{o}
$$

Equation (25) indicates that the relative productivity in the two sectors, oil price and nontradable real marginal cost are the determinants of non-tradable goods price. From equation (25), it would seem, ceteris paribus, that higher oil price and improvement oil sector productivity can lead to increase in the price of non-tradable good. We can also infer that improvement in non-tradable sector productivity may induce lower price for non-tradable goods.

\subsubsection{Importers}

We assume the existence of a retailer importing foreign homogeneous good $Y_{t}^{f}$ from the rest of the world at the foreign currency price $P_{t}^{f *}$. The imported good is packaged into a consumption good $C_{t}^{f}$ at no extra cost and with a zero mark-up. The law of one price (LOOP) operates, such that the domestic price of imported goods is equivalent to the corresponding foreign price denominated by the nominal exchange rate. The domestic price of imports is expressed as follows:

$$
P_{t}^{f}=\frac{P_{t}^{f *}}{S_{t}}
$$

Where $P_{t}^{f}$ is the domestic price of import and $S_{t}$ is the nominal exchange rate. The implication of the LOOP assumption is that there is complete pass-through, which ensures fluctuations in domestic price of imported goods fully reflect changes in foreign price of imports and the exchange rate dynamics.

\subsection{Foreign Production}

The model features a perfectly competitive multi-sector foreign production block, comprising the foreign final goods sector, the foreign intermediate goods sector and the foreign nontradable goods sector in the spirit of Cashin, Céspedes and Sahay (2004) and Hove et al. (2015). Foreign final goods firm uses oil from the SOE as input. It is commonplace in the SOE DSGE literature to assume key foreign economy linkages as a set of exogenous 
Oil Price Shocks and Macroeconomic Dynamics in an Oil-Exporting Emerging Economy: A New Keynesian DSGE Approach

processes, rather than explore the micro-founded equilibrium dynamics. Like the domestic economy, perfect mobility of labour across the three foreign production sectors and the consequent cross sectors wage equalization is assumed.

\subsubsection{Foreign Intermediate and Non-tradable Goods Sectors}

Firms in the foreign intermediate and non-tradable goods production sectors employ linear production technologies. Production function in the foreign non-tradable goods sector is given as:

$$
Y_{t}^{h *}=Z_{t}^{h *} L_{t}^{h *}
$$

Where $Y_{t}^{h *}, Z_{t}^{h *}$ and $L_{t}^{h *}$ represents foreign non-tradable output, foreign non-tradable sector productivity variable and employment in the foreign non-tradable sector, respectively. In the same vein, the foreign intermediate goods production function is modelled linearly as follows:

$$
Y_{t}^{I *}=Z_{t}^{I *} L_{t}^{I *}
$$

Where $Y_{t}^{I *}, Z_{t}^{I *}$ and $L_{t}^{I *}$ are the foreign intermediate sector's output, productivity and employment, respectively. By equating the relative prices in the foreign non-tradable and foreign intermediate sectors $\left(\frac{P_{t}^{h *}}{P_{t}^{* *}}\right)$ to the relative productivity in the foreign intermediate and non-tradable goods sectors $\left(\frac{Z_{t}^{l *}}{Z_{t}^{h *}}\right)$, we can derive the following:

$$
P_{t}^{h *}=\left(\frac{Z_{t}^{I *}}{Z_{t}^{h *}}\right) P_{t}^{I *}
$$

This expresses the price of foreign non-tradables as a product of the relative productivity and foreign intermediate goods price.

\subsubsection{Foreign Tradable Goods Sector}

The foreign tradable goods production sector applies a Cobb-Douglas technology to combine oil imported from the SOE and other oil exporters and foreign produced intermediate good as inputs to produce tradable goods. The production function is as follows:

$$
Y^{f *}=Z_{t}^{f *}\left(Y_{t}^{o *}\right)^{\zeta}\left(Y_{t}^{I *}\right)^{1-\zeta}
$$

Where $Z_{t}^{f *}$ is the foreign tradable goods production sector total factor productivity $Y_{t}^{I *}$, is the foreign intermediate goods inputs and $Y_{t}^{I *}$ is the foreign oil input, a fraction of which 
is imported from the SOE. The parameters $\zeta$ and $1-\zeta$ represent the shares of oil imports and foreign intermediate goods in foreign production, respectively. The cost minimization exercise in the foreign tradable goods sector will result in a cost per unit of output in the following form:

$$
P_{t}^{f *}=\left(P_{t}^{o *}\right)^{\zeta}\left(P_{t}^{I *}\right)^{1-\zeta}
$$

Foreign final goods are assumed to be tradable, allowing its import by the small open economy. Consumption by foreign households is assumed to be symmetric with that of consumers in the domestic economy, thus resulting in an implied foreign consumer price index of the form:

$$
P_{t}^{*}=P_{t}^{h *\left(\psi^{*}\right)} P_{t}^{f *\left(1-\psi^{*}\right)}
$$

Where $\psi^{*}$ and $1-\psi^{*}$ are the weights associated with non-tradable and imported goods, respectively, in the foreign economy's overall consumer price index.

\subsection{Domestic Firms Price Setting}

The non-tradable goods producing firm sets the price of its goods following Calvo (1983)'s staggered pricing rule, which allows price adjustment with some probability. Consequently, at period $\mathrm{t}$, a firm type with the probability $1-\theta^{h}$ can optimally re-set price while another firm type with the probability $\theta^{h}$ cannot re-set price every period and thus, constrained to maintain previous period price. It applies that $\theta^{h} \in(0,1)$ and $\theta^{h}$ is the measure of the degree of stickiness or nominal rigidity in the system. The bigger the stickiness parameter $\theta^{h}$ the less flexible prices are. Taking into account the pricing behaviour of these firms type, a general price index can be constructed as follows:

$$
P_{t}^{h}=\left(1-\theta^{h}\right)\left(P_{t}^{h}\right)^{r e s e t^{1-\mu}}+\theta^{h}\left(P_{t-1}^{h}\right)^{1-\mu \frac{1}{1-\mu}}
$$

Where $\left(P_{t}^{h}\right)^{\text {reset }}$ is the price of the firm that can re-optimize. The maximization problem of the optimizing firm can be set up as follows:

$$
\begin{aligned}
& \operatorname{Max} \sum_{t=0}^{\infty}\left(\theta^{h k}\right) E_{t} \xi_{t+k} Y_{t+k}\left[\left(P_{t}^{h}\right)^{\text {reset }}-N M C_{t+k}^{h}\right] \\
& \text { s.t. } \\
& Y_{t+k} \leq\left(\frac{\left(P_{t}^{h}\right)^{\text {reset }}}{P_{t+k}^{h}}\right)^{-\mu}\left(C_{t+k}^{h}+\left(C_{t+k}^{h}\right)^{\text {reset }}\right)
\end{aligned}
$$


Oil Price Shocks and Macroeconomic Dynamics in an Oil-Exporting Emerging Economy: A New Keynesian DSGE Approach

Where $\left(\theta^{h k} E_{t} \xi_{t+k}\right)$ and $N M C_{t+k}^{h}$ represent the effective stochastic discount factor and the nominal marginal cost, respectively. By this expression, the fraction of firms that can reset prices try to maximize the discounted present value of profit flows subject to the total demand for domestic non-tradable goods. Substituting $Y_{t+k}$ in 34 and factorizing accordingly, the first order condition with respect to $P_{t+k}^{h}$ reset can be obtained as:

$$
\operatorname{Max} \sum_{t=0}^{\infty}\left(\theta^{h k}\right) E_{t} \xi_{t+k} Y_{t+k}\left[\left(P_{t}^{h}\right)^{\text {reset }}-\frac{\mu}{1-\mu} N M C_{t+k}^{h}\right]=0
$$

Following the mathematical procedure shown in Hove et al. (2015) the log-linear expression which depicts the domestic goods inflation as a function of the one-period ahead expected domestic inflation and the real marginal cost of the domestic firm is obtained. This is the New Keynesian Phillips curve equation derived as follows:

$$
\tilde{\pi}_{t}^{h}=\beta E_{t} \widetilde{\pi}_{t+1}^{h}+\kappa_{t}^{h} \widetilde{r m c} c_{t}^{h}
$$

Where $\kappa_{t}^{h}=\frac{\left(1-\beta \theta^{h}\right)\left(1-\theta^{h}\right)}{\theta^{h}}$, being the coefficient of the real marginal cost in the New Keynesian Phillips curve equation.

\subsection{Real Exchange Rate, Oil Price and Imported Inflation}

We follow Cashin et al. (2004) to define the real exchange rate $Q_{t}$ as the foreign price of domestic consumption basket $S_{t} P_{t}$ relative to the foreign price of foreign consumption basket $P_{t}^{*}$. It is the foreign worth of domestic basket of goods relative to the foreign worth of foreign basket of goods, expressed as follows:

$$
Q_{t}=\frac{S_{t} P_{t}}{P_{t}^{*}}
$$

Where $S_{t}$ is the nominal exchange rate, $P_{t}$ is the domestic price index and $P_{t}^{*}$ is the foreign price index. We assume that the law of one price prevails at both ends (i.e. imports and exports) of the domestic economy's tradable sector such that:

$$
\begin{aligned}
& P_{t}^{f}=\frac{P_{t}^{f *}}{S_{t}} \\
& P_{t}^{o}=\frac{P_{t}^{o *}}{S_{t}}
\end{aligned}
$$

Where $P_{t}^{f *}$ and $P_{t}^{o *}$ are the foreign prices of the small open economy's imports and exports (oil), respectively, while $P_{t}^{o}$ is the domestic price of oil. 
Using equations 25, 26 and 29 in 37, we derive the following real exchange rate expression:

$$
Q_{t}=\left(\frac{P_{t}^{o *}}{P_{t}^{I *}} \frac{Z_{t}^{o}}{Z_{t}^{I *}} \frac{Z_{t}^{h *}}{Z_{t}^{h}}\right)^{\psi}\left(\frac{1}{R M C_{t}^{h}}\right)^{\psi}
$$

Where $\frac{P_{t}^{o *}}{P_{t}^{\text {I* }}}$ is the terms of trade between the small open economy's foreign oil price and the foreign economy's intermediate goods price, $\frac{Z_{t}^{o}}{Z_{t}^{*}}$ is the corresponding productivity differential between the domestic oil sector and foreign intermediate goods sector, and $\frac{Z_{t}^{h *}}{Z_{t}^{h}}$ is the productivity differential between foreign and domestic non-tradable sectors. The relative productivity in equation (40) reflect the Harrod-Balassa-Samuelson effect, a theoretical hypothesis credited to the combined contributions of Harrod (1933), Balassa (1964) and Samuelson (1964) on the real exchange rate, relative productivity, relative prices and wages in the non-tradable sector. The Harrod-Balassa-Samuelson Hypothesis posits that, assuming the law of one price hold in the tradable sectors, a shock to productivity in the tradable sector will cause wages to rise, resulting in non-tradable goods price increase and an eventual appreciation of the real exchange rate.

The foremost justification for the above real exchange rate derivation in equation 37 has its root in the literature ${ }^{3}$ which establishes that the equilibrium real exchange rate is largely driven by the long-run evolution of some macroeconomic fundamentals like productivity differentials, terms of trade and real interest rate differentials. In line with this tradition, Cashin et al. (2004) show empirically that real commodity prices constitute the fundamental determinant of the real exchange rate in commodity-exporting countries. Hove et al. (2015) modifies Cashin et al. (2004)'s real exchange rate specification by incorporating the nontradable goods firm's real marginal cost in a new Keynesian small open economy model that identifies commodity terms of trade shock. Following this tradition, we study how a positive shock to the dollar price of oil will affect the oil exporting SOE's business cycle variables within the Gali and Monacelli (2005) small open economy New Keynesian framework and then proceed to explore optimal monetary policy.

Imported inflation is associated with foreign tradable goods, and can be derived with the first difference of equation (31) as:

$$
\pi_{t}^{f *}=\left(\pi_{t}^{o *}\right)^{\zeta^{*}}\left(\pi_{t}^{I *}\right)^{1-\zeta^{*}}
$$

\footnotetext{
${ }^{3}$ See De Gregorio et al. (1994), Rogoff (1996), Chinn and Johnston (1996), Montiel (1997), Kalcheva and Oomes (2007) and Egert and Leonard (2008).
} 
Oil Price Shocks and Macroeconomic Dynamics in an Oil-Exporting Emerging Economy: A New Keynesian DSGE Approach

Similarly, equation (38) is expressed in first difference and equation (41) is substituted into it to obtain following equation (42) as follows:

$$
\pi_{t}^{f}=\left(\frac{\left(\pi_{t}^{o *}\right)^{\zeta^{*}}\left(\pi_{t}^{I *}\right)^{1-\zeta^{*}}}{S_{t}}\right)
$$

This is the modified imported inflation, showing imported inflation as a function of foreign intermediate goods inflation, oil inflation and changes in the nominal exchange rate.

\subsection{International Risk Sharing and the Uncovered Interest Rate Parity}

We assume complete international financial markets, which guarantees domestic economic agents' access to the international financial markets. In the same vein, foreign agents too can access the domestic financial markets. Trading in state-contingent international financial assets is facilitated. Consequently, domestic agents can smooth consumption through subscription to domestic and foreign securities. Assuming both domestic and foreign households exhibit the same preferences and stochastic discount factors, consequent upon which the expected nominal return from domestic risk-free bonds is equal to the expected nominal return from foreign risk-free bonds expressed in terms of the domestic currency; we can derive the condition for international risk sharing. Under this condition, consumption risk is perfectly allocated (shared) between domestic and foreign households by equating the domestic consumption Euler equation to the foreign counterpart, as follows:

$$
\beta E_{t}\left[\left(\frac{C_{t+1}}{C_{t}}\right)^{-\eta}\left(\frac{P_{t}}{P_{t+1}}\right)\right]=\beta E_{t}\left[\left(\frac{C_{t+1}^{*}}{C_{t}^{*}}\right)^{-\eta}\left(\frac{S_{t} P_{t}^{*}}{S_{t+1} P_{t+1}^{*}}\right)\right]
$$

The iterative solution to (43) as in Gali and Monacelli (2005) results in the following:

$$
C_{t}=\Gamma Q_{t}^{\frac{1}{\eta}} C_{t}^{*}
$$

where $\Gamma$ is a constant representing the initial assets position, $Q_{t}$ is the real exchange rate, $C_{t}$ is domestic consumption and $C_{t}^{*}$ is foreign consumption. With the assumption of complete international markets, the condition for the uncovered interest rate parity (UIP) can be derived as follows:

$$
E_{t} \xi_{t+1}\left(R_{t}-R_{t}^{*} \frac{S_{t+1}}{S_{t}}\right)=0
$$

where $\xi_{t+1}$ is the stochastic discount factor, $R_{t}$ is the domestic interest rate and $R_{t}^{*}$ is the foreign interest rate. The UIP condition depicts the relationship between expected variation in 
nominal exchange rates and differential in interest rates in the domestic and foreign economy. The expression indicates that movements in the nominal exchange rate is linked to the gap (wedge) between domestic and foreign nominal interest rates.

\subsection{Monetary Policy}

To close the model, monetary policy is captured as central bank's policy reaction function; a Taylor (1993)-type interest rate feedback rule. The Taylor rule is a prescription for how a central bank should set monetary policy rate to promote healthy macroeconomic conditions. In keeping with this tradition, we employ an interest rate rule with which the central bank is assumed to act or respond to stabilize output, inflation and the exchange rate. The rule is notable in the literature for the merits it holds for monetary policy modelling. Clarida, Gali and Gertler (1999) and Lubik and Schorfheide (2007) believe the rule summarizes well monetary policy patterns and behaviour in many policy environments. Also, Clarida, Gali and Gertler (1999) and Woodford (2003) attest to the general robustness and consistency of the rules with the fundamental principles of optimal monetary policy. For now, there is a seeming consensus both in the literature and in policy circles that stabilizing inflation around a target and output around its trend should constitute the fundamental goals of monetary policy. Such a policy framework is popularly known as flexible inflation targeting and it fits the Taylor rule setup. The flexibility of the Taylor rule makes it possible to nest a rich set of alternative monetary policy frameworks, especially in developing and emerging market economies where different monetary policy regimes may be in vogue at different times (Senbeta, 2011). From a modelling standpoint, Clarida et al. (1999) submits that Taylor rules are known to provide equilibrium determinacy, a requirement for achieving a unique stationary equilibrium solution in rational expectations models. It must be added that, Taylor's prescription that the asymptotic response of the policy rate to inflation must be higher than unity is required for achieving model stability.

\subsubsection{Generalized Taylor Rule}

We adopt a generalized Taylor rule in which the central bank manipulates the nominal interest rate in response to deviations of output, inflation and exchange rate from their steady-state values. This is in the spirit of Senbeta (2011) and Hove et al. (2015) as follows:

$$
R_{t}=R_{t-1}^{\rho_{r}}\left[\left(\frac{Y_{t}}{\bar{Y}}\right)^{\Phi_{1}}\left(\frac{\pi_{t}}{\bar{\pi}}\right)^{\bar{\omega}_{2}}\left(\frac{\pi_{t}^{h}}{\bar{\pi}^{h}}\right)^{\Phi_{3}}\left(\frac{S_{t} / S_{t-1}}{\bar{S}}\right)^{\omega_{4}}\right]^{1-\rho_{r}}
$$


Oil Price Shocks and Macroeconomic Dynamics in an Oil-Exporting Emerging Economy: A New Keynesian DSGE Approach

Where $\varpi_{1}, \varpi_{2}, \varpi_{3}$ and $\varpi_{4}$ are weights attached by the monetary authority to output, CPI inflation, non-tradable inflation and movement in the exchange rate, respectively. Each weight indicates the importance of their respective coefficient variables in the central bank policy reaction function. The term $\rho_{r}$ is the smoothing parameter, which captures history dependency of policy in the model (Woodford, 2003). Empirical results have shown that monetary policy innovations rarely radically depart from recent history, rather interest rate changes often reflect a sequence of small adjustments in the same direction (Clarida et al., 1999). In addition, Sack and Wieland (2000) maintains that concerns about model parameter uncertainty and financial system stability concerns makes interest rate smoothing appealing to central banks. It ensures that monetary policy innovations do not become disruptive, surprise the markets unnecessarily and elicit unintended macroeconomic volatility.

\subsubsection{Alternative Monetary Policy Rules}

From the generalized Taylor rule in 46, we assume the following three alternative monetary policy regimes which inform the set of policy objectives being targeted by the central bank:

$$
\begin{aligned}
& R_{t}=R_{t-1}^{\rho_{r}}\left[\left(\frac{Y_{t}}{\bar{Y}}\right)^{\Phi_{1}}\left(\frac{\pi_{t}}{\bar{\pi}}\right)^{\omega_{2}}\right]^{1-\rho_{r}} \\
& R_{t}=R_{t-1}^{\rho_{r}}\left[\left(\frac{Y_{t}}{\bar{Y}}\right)^{\Phi_{1}}\left(\frac{\pi_{t}^{h}}{\overline{\pi^{h}}}\right)^{\sigma_{3}}\right]^{1-\rho_{r}} \\
& R_{t}=R_{t-1}^{\rho_{r}}\left[\left(\frac{Y_{t}}{\bar{Y}}\right)^{\Phi_{1}}\left(\frac{S_{t} / S_{t-1}}{\bar{S}}\right)^{\omega_{4}}\right]^{1-\rho_{r}}
\end{aligned}
$$

Equations 47, 48 and 49 are the CPI inflation, non-tradable inflation and exchange rate targeting regimes, respectively. Under all the three frameworks, the monetary authority is assumed to be interested in employment level, as such it observes the behaviour of aggregate output under all the alternative monetary policy rules. The significance of output in the Taylor rule is well recognized by Galí (2015) who argues that even "inflation targeters" do not claim to be seeking to stabilize inflation all the time without due consideration for how that would impact real variables like output and employment. The inclusion of the exchange rate in the central bank feedback rule does not necessarily mean that the central bank explicitly pegs the exchange rate, rather it indicates that significant volatility in the exchange rate could elicit a policy response from the monetary authority. 


\subsection{Equilibrium Conditions and Aggregate Resource Constraints}

In equilibrium, the demand and supply for tradable goods, non-tradable goods and labour must attain parity. For the goods market, the clearing conditions is such that sum of demand for non-tradable output and oil output (export) must be equal to total domestic production, and can be represented as:

$$
Y_{t}=Y_{t}^{h}+Y_{t}^{o}
$$

where $Y_{t}^{h}=C_{t}^{h}$ and $Y_{t}^{o}=C_{t}^{o}$. Given these relationships, the CPI equation in 8 is substituted into $C_{t}^{h}$ in equation 5 to derive:

$$
Y_{t}^{h}=\psi\left(\frac{P_{t}^{h}}{P_{t}^{f *}} S_{t}\right)^{-v(1-\psi)} C_{t}
$$

Similarly, given that $Y_{t}^{o}=Y_{t}^{o *}=C_{t}^{o}$ in the oil sector and using the equation for the demand for oil (export), we can express oil consumption as follows:

$$
Y_{t}^{o}=\left(\frac{1-\zeta^{*}}{\zeta^{*}}\right)^{\zeta^{*}} Y_{t}^{f *}\left(\frac{P_{t}^{o *}}{P_{t}^{I *}}\right)^{\zeta^{*}}
$$

The parameter $\zeta^{*}$ is the share of exported oil in the foreign economy's production. Having derived the two equilibrium conditions that matter in the goods market, we can combine the log-linearized versions of (51) and (52) with the steady state ratios of non-oil and oil output to total income to derive the log-linear equilibrium expression representing the small open economy's IS equation. The supply side of the equilibrium dynamics can be obtained using the derived marginal costs in the oil and non-tradable sectors. Elements of the oil sector real marginal cost in equation 17 and non-tradable sector real marginal cost in equation 21 are substituted to obtain the equilibrium real marginal costs in the two sectors.

The clearing condition for the labour market is such that the sum of employment in the oil and non-tradable sectors must be equal to the total labour supply in the economy. It is represented as follows:

$$
L_{t}=L_{t}^{o}+L_{t}^{h}
$$

We derive the equilibrium dynamics in the labour market by substituting out (16) and (20) into (53). The model's equilibrium solution is computed using the optimal outcomes from 
Oil Price Shocks and Macroeconomic Dynamics in an Oil-Exporting Emerging Economy: A New Keynesian DSGE Approach

(a) household's problem, (b) firm's problem and (c) pricing decisions and price indices, all market clearing conditions, monetary policy rule, interest rate parity condition, foreign economy's equilibrium identities and the exogenous shock processes.

\section{Parameter Calibration, Model Solution and Simulation}

To analyse the impact of a positive oil price shock, the model's structural parameters are calibrated to match the general features of small open economies exporting primary products and to reflect specific characteristics of the Nigerian economy. In doing this, we rely on the wider small open economy literature, the limited literature on Nigeria and comparable emerging and developing economies business cycle characteristics and data-driven estimates from time series procedures. The key ratios are obtained using data sourced from the International Monetary Fund (IMF), the World Bank and the Central Bank of Nigeria (CBN).

As shown in Table 1, the subjective discount factor $\beta$ is set at 0.99 implying that steady state real interest is in the neighbourhood of $4 \%$ annually. The inverse of the elasticity of intertemporal substitution, being the risk aversion parameter $\eta$ is calibrated as 1 , in line with estimate obtained by Steinbach, Mathuloe and Smith (2009) for South Africa, a commodity exporter. The elasticity of the marginal dis-utility of labour $\varrho$ is set at 6 following estimates in Alpanda, Kotzé and Woglom (2010). The share of non-traded goods in total domestic consumption, $\Psi$ and the share of imports in total domestic consumption, otherwise known as the degree of openness, $1-\Psi$ are estimated at 0.8 and 0.2 , respectively. The estimate is based on the average import to GDP ratio for Nigeria between 1981 and 2015. For the foreign economy, in line with the earlier assumption of consumption symmetry between domestic and foreign households, the share of non-tradable goods in total consumption is given as 0.8 .

We follow Santacreu (2014) and Alpanda et al. (2010) in setting the persistence of the productivity variables in the oil, $\rho_{z^{o}}$ and non-oil, $\rho_{z^{h}}$ sectors to 0.85 and 0.74 , respectively; and the foreign intermediate and non-traded goods sectors both have productivity variables $\rho_{z^{*}}$ and $\rho_{z^{h *}}$ persistence of 0.8 . The persistence parameters for foreign interest rate $\rho_{r *}$, foreign oil price $\rho_{p^{o *}}$, foreign oil inflation $\rho_{\pi^{o *}}$, foreign intermediate goods price $\rho_{p^{I *}}$, and the foreign intermediate goods inflation $\rho_{\pi^{I *}}$ are set at $0.8,0.8,0.5$, and 0.5 , respectively; while the share of oil in foreign production $\zeta^{*}$ is calibrated at 0.26 in line with Hove et al. (2015). The probability that firms are unable to re-optimize every period, otherwise referred to as 
the stickiness or nominal price rigidity parameter $\theta^{h}$ is given as 0.75 in line with Christiano, Eichenbaum and Evans (2005) and Gali and Monacelli (2005); suggesting that price adjustment is achieved averagely once in every four (4) quarters. The smoothing parameter $\rho_{r}$ for the Taylor rule, following Ortiz and Sturzenegger (2007), is set at 0.73. The parameter is used to assure economic agents on the trajectory of monetary policy stance and to anchor expectations about the evolution of interest rate in the economy.

The monetary policy parameters in the Taylor rule $\varpi_{1}, \varpi_{2}, \varpi_{3}$ and $\varpi_{4}$ are fixed at $0.5,1.5,1.5$ and 0.25 ; respectively, reflecting the extent to which the policy maker cares about stabilising the individual variables in the rule. The parameters for aggregate inflation $\left(\varpi_{2}\right)$ and domestic inflation $\left(\varpi_{3}\right)$ are set at 1.5 . This is to satisfy the Taylor principle ${ }^{4}$, reflect the importance of inflation stabilisation in the central bank's reaction function and to satisfy the technical requirement for model determinacy (Taylor, 1993 and Asso, Kahn \& Leeson, 2010). The type of Taylor rules that incorporate exchange rate element is in the category of the modified Taylor rules common with small open, emerging markets and developing economies. The modification of the traditional Taylor rule to account explicitly for the exchange rate in setting monetary policy instrument is consistent with an inflation targeting monetary policy framework (Mishkin, 2007). Generally, in many inflation targeting regimes, especially the class being modelled here, stabilization of output and exchange rate in addition to inflation are accommodated in the monetary policy reaction function. Weights assigned to CPI and domestic inflation satisfies the Taylor principle, which recommends an aggressive stance to inflation; while values assigned to output and exchange rate are consistent with those employed by Steinbach et al. (2009) and Zeufack, Kopoin, Nganou, Tchana and Kemoe (2016). The coefficient of real marginal cost $\left(\kappa_{t}^{h}=\frac{\left(1-\beta \theta^{h}\right)\left(1-\theta^{h}\right)}{\theta^{h}}\right)$ in the new Keynesian Philips curve equation is obtained as 0.0825 ; while the elasticity of substitution within each goods category (i.e. non-tradable and imports) and between the two goods categories are set at 10 and 1, respectively, corresponding to values in Romero (2008) and Hove et al. (2015).

\footnotetext{
${ }^{4}$ The Taylor principle requires that weights assigned to any measure of inflation should be greater than 1 , to capture monetary policy's aggressive response to inflation and to ensure model solution.
} 
Oil Price Shocks and Macroeconomic Dynamics in an Oil-Exporting Emerging Economy: A New Keynesian DSGE Approach

Table 1: Model Parameters Calibration

\begin{tabular}{lll}
\hline Parameter & Description & Value \\
\hline$\beta$ & Discount Factor & 0.99 \\
$\eta$ & Risk aversion parameter & 1 \\
$\varrho$ & Elasticity of marginal dis-utility of labour & 6 \\
$\psi$ & Non-traded goods share in total consumption & 0.8 \\
$v$ & Elasticity of substitution within each goods category & 10 \\
$v$ & Elasticity of substitution between goods categories & 1 \\
$\rho_{z^{o}}$ & Oil sector productivity persistence & 0.85 \\
$\rho_{z^{h}}$ & Non-oil sector productivity persistence & 0.74 \\
$\rho_{z^{I *}}$ & Foreign intermediate goods productivity persistence & 0.8 \\
$\rho_{z^{h *}}$ & Foreign non-traded goods persistence & 0.8 \\
$\rho_{r^{*}}$ & Foreign interest rate persistence & 0.8 \\
$\rho_{p^{o *}}$ & Foreign oil price persistence & 0.8 \\
$\rho_{\pi^{o *}}$ & Foreign oil inflation persistence & 0.8 \\
$\rho_{p^{I *}}$ & Foreign intermediate goods price persistence & 0.8 \\
$\rho_{\pi^{I *}}$ & Foreign intermediate goods inflation persistence & 0.8 \\
$\zeta^{*}$ & Share of oil in foreign production & 0.26 \\
$\theta^{h}$ & Nominal price rigidity parameter & 0.75 \\
$\rho_{r}$ & Interest rate smoothing parameter & 0.73 \\
$\varpi_{1}$ & Output weight in the Taylor rule & 0.5 \\
$\varpi_{2}$ & Aggregate inflation weight in the Taylor rule & 1.5 \\
$\varpi_{3}$ & Domestic inflation weight in the Taylor rule & 1.5 \\
$\varpi_{4}$ & Exchange rate weight in the Taylor rule & 0.25 \\
$\kappa_{t}^{h}$ & Coefficient of real marginal cost & 0.0825 \\
\hline
\end{tabular}

Table 2: Model Steady State Ratios

\begin{tabular}{lll}
\hline $\begin{array}{l}\text { Steady State } \\
\text { Ratios }\end{array}$ & Description & Value \\
\hline$\overline{Y_{t}^{h}}$ & Ratio of non-tradable output to total income & 0.75 \\
$\overline{\frac{Y_{t}}{Y_{t}^{o}}}$ & Ratio of oil output to total income & 0.25 \\
$\overline{\frac{\bar{Y}_{t}}{L^{h}}}$ & Ratio of non-oil employment to total & 0.65 \\
$\overline{\bar{L}}$ & Ratio of oil employment to total & 0.35 \\
\hline $\bar{L}$ &
\end{tabular}

Using the macroeconomic fundamentals of Nigeria and data sourced from the IMF IFS and the Nigerian Bureau of Statistics (NBS) and the Central Bank of Nigeria (CBN), we obtain the steady state ratios for non-tradable output to total income $\frac{\overline{Y_{t}^{h}}}{\bar{Y}_{t}}$, oil output (exports) to total income $\frac{\overline{Y_{t}^{o}}}{\overline{Y_{t}}}$, non-tradable sector employment to total employment $\frac{\overline{L^{h}}}{\bar{L}}$ and oil sector employment to total employment $\frac{\overline{L^{o}}}{\bar{L}}$ as $0.75,0.25,0.65$ and 0.35 ; respectively.

We solved the model in Dynare application, a toolbox on MATLAB after deriving the first order conditions of all optimizing agents, the equilibrium conditions and specifying the shock processes. Dynare utilizes the Blanchard and Khan (1980) procedure to derive model solu- 
tions. We proceed to simulate the model to examine how a positive shock to the oil price affects key macroeconomic variables in the economy over forty period horizon.

\section{Analysis of Results}

We apply ten standard deviation positive shock to the international price of oil and observe the impulse responses of selected macroeconomic variables, including; aggregate output, domestic output, oil export, consumption, employment, real exchange rate, imported inflation, aggregate inflation and interest rate under three alternative monetary policy frameworks. The impulse response functions are compared given alternative monetary policy regimes: (i) CPI inflation targeting rule; (ii) non-tradable inflation targeting rule; and (iii) exchange rate targeting rule; to determine the policy regime with lower volatility and better macroeconomic outcomes. Figure 2 below shows the impulse responses of shock to oil price under the three alternative policy rules.

An oil price shock is shown to increase the volume of oil exports. Exogenous increase in oil price decreases oil sector real marginal cost and raises oil supply, resulting in higher oil exports and aggregate output. The oil sector exhibits significant sensitivity to oil price movements. The monetary policy rule that targets the consumer price index (CITR) elicits the largest oil sector response to the shock.

This indicates that the CPI inflation targeting regime (CITR) provides the most auspicious monetary policy environment for the oil sector to thrive whenever oil price rises. Although, the domestic inflation targeting regime (DITR) and the exchange rate targeting regime (ERTR) provide nearly the same magnitude of oil output response to the positive shock to oil price, the CITR clearly outperforms them. In addition, oil price shock effects on oil output under DITR and ERTR is more volatile given that the initial increase in oil output turned into a decline by the sixth quarter before becoming fully dissipated with that of the CITR in the thirtieth quarter.

Conversely, the non-tradable (domestic) output sector nose-dived in response to a positive oil price shock. Non-oil output declined on impact in response to the positive innovation to oil price under all the three alternative monetary policy rules. The non-tradable output fall under the CITR is worse than those under the DITR and ERTR. The phenomenon ${ }^{5}$ in

\footnotetext{
${ }^{5}$ See Corden(1984), Egert and Leonard(2008), Kalcheva and Oomes (2007) and Benkhodja (2014)
} 
Oil Price Shocks and Macroeconomic Dynamics in an Oil-Exporting Emerging Economy: A New Keynesian DSGE Approach

Oladunni

which boom in the resource sector results in the depression of the domestic non-resource sector as in this case is known as the Dutch disease, a problem to which many developing resource-rich economies are susceptible. In this respect, we find evidence of the operation of the two principal mechanisms of the Dutch disease; viz: the resource movement effect and the wealth/spending effect.
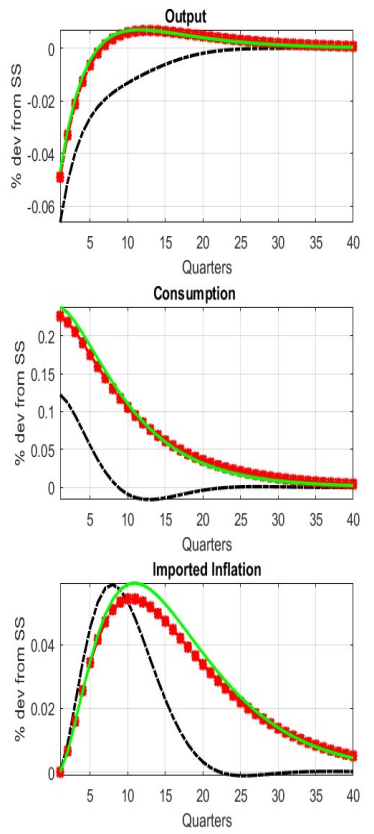

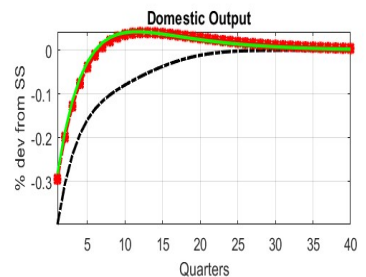

Employment
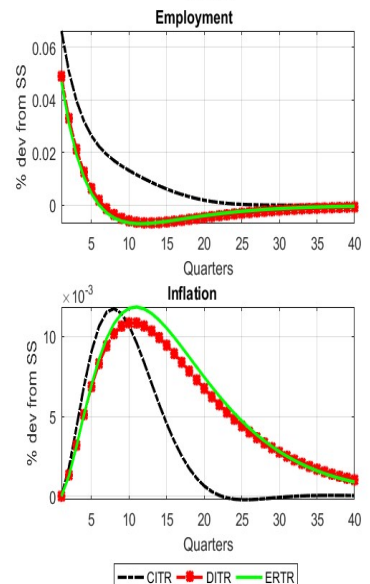

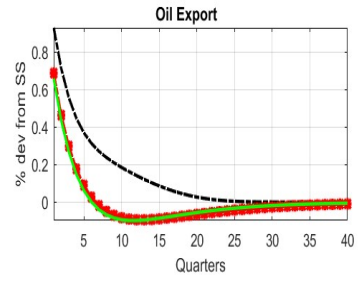

Real Exchange Rate
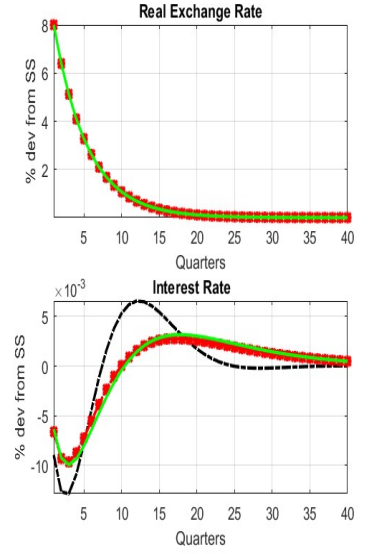

Figure 2: Responses to a positive oil price shock under alternative Monetary Policy Regimes

The resource movement effect is associated with the migration of productive (labour) resource from the non-tradable goods sector to the oil sector, where the marginal productivity of labour had risen due to improved oil sector performance. Also, the improved oil sector performance resulted in the generation of new employment opportunities leading to higher employment level. Conversely, the exodus or movement of workers from the non-tradable sector to the oil sector is a causal factor in the decline experienced in the non-tradable sector. Additionally, given the size of the non-tradable sector, its decline resulted in the overall output slump. However, while the shock elicits decline in both non-tradable and total output, the percentage increase in the oil output is by far higher than the percentage fall in both nontradable and overall output. This development has important implications for employment 
and consumption. The booming oil sector characterized by improved wages attracts workers from the non-traded goods sector and creates new employment opportunities for labour force participants. This results in a rise in total employment. Employment is found to be more responsive to an oil price shock under the CITR compared to both DITR and ERTR that often trail each other.

In the same vein, consumption exhibit a positive response to oil price shock. Given that more people are now in work as a result of the oil windfall, higher marginal productivity of labour in the oil sector will propel higher wages and consequently, higher consumption; allowing the spending effect to manifest through higher demand for consumer goods in the economy. Comparatively, consumption is shown to be more sensitive to oil price shock under ERTR and DITR than the CITR. This implies that consumption growth in response to oil price shock is more contained and less volatile under a monetary policy rule that targets the composite measure of inflation. Furthermore, we can infer that the consequent increase in consumption is oriented towards imported goods, given that exchange rate appreciation will make imported goods more attractive to domestic consumers and the effects of the Dutch disease cannot allow the domestic non-tradable sector to respond immediately to higher demand. Consumption stabilization is better attained under the CITR compared with under both ERTR and DITR, under which consumption response to an oil price shock is more amplified. Given the circumstances of the Dutch disease and real exchange rate appreciation, higher consumption in response to oil price shocks under ERTR and DITR may build external account vulnerabilities which could undermine the economy's current account and balance of payments position. A situation where output falls, yet consumption rises as exchange rate appreciation encourages higher imports bills which may precipitate a range of external sector problems such as loss of domestic competitiveness, unsustainable import bills, high imported inflation, external reserves pressure and a potential currency crisis if oil market conditions reverses.

Oil price shock results in the appreciation of the real exchange rate. This is attributable to the consequent rise in oil sales receipts or foreign exchange. Combined with the wealth effect, real exchange rate appreciation provides domestic consumers with an additional incentive to consume more imported goods. Whenever, the real exchange rate appreciates, the relative price of imports falls, and domestic consumers consume more. In any case, the non-tradable 
Oil Price Shocks and Macroeconomic Dynamics in an Oil-Exporting Emerging Economy: A New Keynesian DSGE Approach

sector is already on the decline and cannot adjust to the improved domestic demand propelled by the oil boom. Oil price shock produced the same high magnitude of exchange rate appreciation under the three (3) policy rules; suggesting that oil earnings play a very critical role in the real exchange rate determination process in developing oil exporting small open economies. It does not matter, what monetary policy regime is in practice, an oil price shock would elicit a similar response in the real exchange rate of a developing economy that exports oil.

The effect of oil price shock on inflation is not manifest on impact, however, it shows that a positive inflation expectation exists, and that actual inflation may rise in the medium-tolong term. Therefore, the concern about inflation is palpable among domestic economic agents and the principal source of the inflation expectations is the price index of imported goods. Whereas, inflation tend to be more responsive and volatile under the CITR, it is more persistent under the DITR and ERTR.

Given that there is no immediate threat of inflation the central bank has no incentive to tighten the stance of policy. Conversely, the effect of the Dutch disease on the non-tradable output sector compels the central bank to lower the interest rate. The significant decline in nontradable output which accounts for the marginal decline in the economy's overall output leads to an interest rate cut, given that the central bank's reaction function envisages output performance as an objective in the Taylor rule. Mishkin (2007) notes that central banks focus on output stabilization enjoys two main merits. The first is in connection with conclusions from the canonical aggregate supply models of Svensson (1997) and Clarida et al. (1999) which indicates that variation in inflation is influenced by output gap; and the second is that the general public also care about the trade-off between output and inflation fluctuations. Also, output volatility is important for the setting of monetary policy because it affects the forecast of future inflation and has implications for welfare.

The central bank, therefore, is compelled to act through an accommodative monetary policy to address the negative deviation of output from steady state. Moreover, the real exchange rate appreciation occasioned by the oil price shock may provide an additional impetus for the central bank to ease monetary policy with the intent to re-inflate the non-tradable sector and boost overall output. Interest rate cut is sharper under the CITR, the normalization of monetary policy through rate hike is also sharper under the CITR, with interest rate response 
dissipating faster than under the alternative policy rules. Under both DITR and ERTR however, the cut in interest rate was benign, policy normalization was slower and policy response took a longer time to dissipate. On the whole, the point where policy normalization (interest rate response climbed to positive territory) began are shown to coincide with the points where both imported and CPI inflation pressures became manifest and at these points, output declines had dissipated, especially under the DITR and ERTR. These interactions tend to indicate the central bank's readiness to contain inflation aggressively whenever the threat emerges.

\section{Summary, Conclusion and Policy Recommendations}

In a two-sector small open economy model featuring price stickiness in the non-traded sector and calibrated to highlight some stylized facts about oil exporting emerging and developing small open economies, we study the dynamic responses of selected macroeconomic variables to a positive oil price shock and the alternative optimal paths for monetary policy given the shock. The study establishes the Dutch disease, consequent upon a positive oil price shock and finds that monetary policy responds with an easy policy in pursuit of domestic output stabilization.

The incidence of Dutch disease in the economy is found to be more amplified under the CPI targeting rule, as both non-tradable output and total output declined in response to the positive oil price shock. In addition, given that the magnitude of the rise in oil output induced by the oil boom exceeds the size of the decline in domestic output, the net effect resulted to an increase in employment and consumption levels. The income effect from the higher hours of work and the wealth effect resulting from the boom can explain the rise in consumption. Exchange rate appreciation is significant and similar under the three policy regimes; while the threat of inflation is largely subdued, although a positive inflation expectation abounds in the economy.

It is imperative for oil-endowed emerging economies to address the persistent Dutch disease debacle, which tends to undermine balanced and sustainable growth. The non-oil sector should be insulated from the adverse effect of oil price oscillation by decoupling the wider economy from the direct macroeconomic fallouts of oil price shocks. In conclusion, we reckon that our results may be slightly or significantly different if a sizable proportion of 
Oil Price Shocks and Macroeconomic Dynamics in an Oil-Exporting Emerging Economy: A New Keynesian DSGE Approach

exported oil is utilized domestically. In other words, adding value to and utilizing a reasonable proportion of oil produced in oil-endowed emerging economies may help minimise the vulnerability of the non-oil sector to the shock.

\section{References}

Adebiyi, A., \& Mordi, C. N. (2012). A dynamic stochastic general equilibrium (DSGE) model of oil price shocks and exchange rate pass-through to domestic inflation in Nigeria (No. 3715). EcoMod.

Akpan, E. O. (2009). Oil price shocks and Nigeria's Macroeconomy. In A Paper Presented at the Annual Conference of CSAE Conference, Economic Development in Africa, 2224.

Alege, P. O. (2008). Macroeconomic policies and business cycles in Nigeria: 1970-2004. Doctoral dissertation, Covenant University.

Algozhina, A. (2016). Monetary policy rule, exchange rate regime, and fiscal policy cyclicality in a developing oil economy.CERGE-EI Working Paper Series, (572).

Allegret, J. P., \& Benkhodja, M. T. (2015). External shocks and monetary policy in an oil exporting economy (Algeria). Journal of Policy Modeling, 37(4), 652-667.

Alpanda, S., Kotzé, K., \& Woglom, G. (2010). The role of the exchange rate in a New Keynesian DSGE model for the South African economy. South African Journal of Economics, 78(2), 170-191.

Andrés, J., David López-Salido, J., \& Vallés, J. (2006). Money in an estimated business cycle model of the euro area. The Economic Journal, 116(511), 457-477.

Asso, P. F., Kahn, G. A., \& Leeson, R. (2010). The Taylor rule and the practice of central banking. Available at SSRN 1553978.

Backus, D. K., \& Crucini, M. J. (2000). Oil prices and the terms of trade. Journal of international Economics, 50(1), 185-213.

Balassa, B. (1964). The purchasing-power parity doctrine: a reappraisal. Journal of political Economy, 72(6), 584-596.

Barsky, R. B., \& Kilian, L. (2001). Do we really know that oil caused the great stagflation? A monetary alternative. NBER Macroeconomics annual, 16, 137-183.

Benkhodja, M. T. (2014). Monetary policy and the Dutch disease effect in an oil exporting economy. International Economics, 138, 78-102. 
Bernanke, B. S., Gertler, M., Watson, M., Sims, C. A., \& Friedman, B. M. (1997). Systematic monetary policy and the effects of oil price shocks. Brookings papers on economic activity, 1, 91-157.

Blanchard, O. J., \& Gali, J. (2007). The Macroeconomic Effects of Oil Shocks: Why are the 2000s so different from the 1970s? (No. w13368). National Bureau of Economic Research.

Blanchard, O. J., \& Kahn, C. M. (1980). The solution of linear difference models under rational expectations. Econometrica: Journal of the Econometric Society, 1305-1311.

Blanchard, O., \& Galí, J. (2010). Labor markets and monetary policy: A New Keynesian model with unemployment. American economic journal: macroeconomics, 2(2), 1-30.

Bodenstein, M., Guerrieri, L., \& Kilian, L. (2012). Monetary policy responses to oil price fluctuations. IMF Economic Review, 60(4), 470-504.

Calvo, G. A. (1983). Staggered prices in a utility-maximizing framework. Journal of monetary Economics, 12(3), 383-398.

Cashin, P., Céspedes, L. F., \& Sahay, R. (2004). Commodity currencies and the real exchange rate. Journal of Development Economics, 75(1), 239-268.

Chinn, M., \& Johnston, L. (1996). Real exchange rate levels, productivity and demand shocks: evidence from a panel of 14 countries. (No. w5709). National Bureau of Economic Research.

Christiano, L. J., Eichenbaum, M., \& Evans, C. L. (2005). Nominal rigidities and the dynamic effects of a shock to monetary policy. Journal of political Economy, 113(1), $1-45$.

Clarida, R., Gali, J., \& Gertler, M. (1999). The science of monetary policy: a new Keynesian perspective. Journal of economic literature, 37(4), 1661-1707.

Corden, W. M. (1984). Booming sector and Dutch disease economics: survey and consolidation. oxford economic Papers, 36(3), 359-380.

De Gregorio, J., Giovannini, A., \& Wolf, H. C. (1994). International evidence on tradables and nontradables inflation. European Economic Review, 38(6), 1225-1244.

Devereux, M. B., Lane, P. R., \& Xu, J. (2006). Exchange rates and monetary policy in emerging market economies. The Economic Journal, 116(511), 478-506.

Dixit, A. K., \& Stiglitz, J. E. (1977). Monopolistic competition and optimum product diversity. The American economic review, 67(3), 297-308.

Egert, B., \& Leonard, C. S. (2008). Dutch disease scare in Kazakhstan: Is it real? Open Economies Review, 19(2), 147-165. 
Oil Price Shocks and Macroeconomic Dynamics in an Oil-Exporting Emerging Economy: A New Keynesian DSGE Approach

Ferrero, A., \& Seneca, M. (2019). Notes on the Underground: Monetary Policy in ResourceRich Economies. Journal of Money, Credit and Banking , 51(4), 953-976.

Fukač, M., \& Pagan, A. (2010). Limited information estimation and evaluation of DSGE models. Journal of Applied Econometrics, 25(1), 55-70.

Galí, J. (2015). Monetary policy, inflation, and the business cycle: an introduction to the new Keynesian framework and its applications.Princeton University Press.

Gali, J., \& Monacelli, T. (2005). Monetary policy and exchange rate volatility in a small open economy. The Review of Economic Studies, 72(3), 707-734.

Hamilton, J. D. (2003). What is an oil shock?. Journal of econometrics,113(2), 363-398.

Harrod, R. F. (1933). International Economics Cambridge: Nisbet and Cambridge University Press.

Hove, S., Mama, A. T., \& Tchana, F. T. (2015). Monetary policy and commodity terms of trade shocks in emerging market economies. Economic Modelling, 49, 53-71.

Iklaga, F. O. (2017). Estimated and optimised monetary policy rules for resource-rich emerging economies. Doctoral dissertation, University of Surrey.

Kalcheva, K., \& Oomes, N. (2007). Diagnosing Dutch disease: does Russia have the symptoms? (No. 7-102). International Monetary Fund.

Kilian, L. (2008). The economic effects of energy price shocks. Journal of Economic Literature, 46(4), 871-909.

Kilian, L., \& Lewis, L. T. (2011). Does the Fed respond to oil price shocks?. The Economic Journal, 121(555), 1047-1072.

Kilishi, A. A. (2010). Oil price shocks and the Nigeria economy: A variance autoregressive (VAR) model. International Journal of Business and Management, 5(8), 1835-5412.

Kim, I. M., \& Loungani, P. (1992). The role of energy in real business cycle models.Journal of Monetary Economics, 29(2), 173-189.

Leduc, S., \& Sill, K. (2004). A quantitative analysis of oil-price shocks, systematic monetary policy, and economic downturns. Journal of Monetary Economics, 51(4), 781808.

Lee, K., \& Ni, S. (2002). On the dynamic effects of oil price shocks: a study using industry level data.Journal of Monetary economics, 49(4), 823-852.

Lubik, T. A., \& Schorfheide, F. (2007). Do central banks respond to exchange rate movements? A structural investigation. Journal of Monetary Economics, 54(4), 1069-1087. 
Lubik, T., \& Schorfheide, F. (2005). A Bayesian look at new open economy macroeconomics. NBER macroeconomics annual, 20, 313-366.

McCallum, B. T., \& Nelson, E. (1999). Nominal income targeting in an open-economy optimizing model. Journal of Monetary economics, 43(3), 553-578.

Medina, J. P., \& Soto, C. (2005). Oil shocks and monetary policy in an estimated DSGE model for a small open economy.Documento de Trabajo,353.

Mishkin, F. S. (2007). Monetary policy strategy. MIT press.

Montiel, P. (1997). The theory of the long-run equilibrium Real exchange rate. Mimeo, The World Bank.

Nason, J. M., \& Cogley, T. (1994). Testing the implications of long-run neutrality for monetary business cycle models. Journal of Applied Econometrics, 9(S1), S37-S70.

Oladunni, S. (2019). External shocks and business cycle fluctuations in oil-exporting small open economies. CBN Journal of Applied Statistics, 10(2), 39-71.

Olayeni, O. R. (2009). A small open economy model for Nigeria: a BVAR-DSGE approach. Available at SSRN 1432802.

Olekah, J. K. A., \& Oyaromade, R. (2007). Estimating a DSGE model of the Nigerian Economy. In Draft Presented at the 12th African Econometric Society (AES) Conference in Cape Town, South Africa, July 4-6, 2007.

Omotosho, B. S. (2019). Oil price shocks, fuel subsidies and macroeconomic (in) stability in Nigeria. CBN Journal of Applied Statistics, 10(2), 1-38.

Omran, V. T., Ehsani, M. A., \& Khyareh, M. M. (2015). Optimal Monetary Policy Rules in Iran: A Welfare Analysis.IUP Journal of Applied Economics, 14(3), 7.

Ortiz, A., \& Sturzenegger, F. (2007). Estimating SARB's policy reaction rule. South African Journal of Economics, 75(4), 659-680.

Otaha, J. I. (2012). Dutch disease and Nigeria oil economy. African Research Review, 6(1), $82-90$

Rasaki, M. G. (2017). An Estimated New Keynesian Phillips Curve for Nigeria. Acta Universitatis Danubius. Economica, 13(2), 203-211.

Rogoff, K. (1996). The purchasing power parity puzzle. Journal of Economic literature, 34(2), 647- 668.

Romero, R. E. (2008). Monetary policy in oil-producing economies. Center for Economic Policy Studies. 
Oil Price Shocks and Macroeconomic Dynamics in an Oil-Exporting Emerging Economy: A New Keynesian DSGE Approach

Sack, B., \& Wieland, V. (2000). Interest-rate smoothing and optimal monetary policy: a review of recent empirical evidence. Journal of Economics and Business, 52(1-2), 205-228.

Samuelson, P. A. (1964). Theoretical notes on trade problems. The review of economics and statistics, 145-154.

Santacreu, A. M. (2014). Reaction functions in a small open economy: What role for nontraded inflation?.Federal Reserve Bank of St. Louis Working Paper Series, 2014-044.

Schorfheide, F. (2000). Loss function-based evaluation of DSGE models. Journal of Applied Econometrics, 15(6), 645-670.

Senbeta, S. R. (2011). A Small Open Economy New Keynesian DSGE model for a foreign exchange constrained economy. Available at SSRN 1812743.

Smets, F., \& Wouters, R. (2003). An estimated dynamic stochastic general equilibrium model of the euro area. Journal of the European economic association, 1(5), 11231175 .

Steinbach, M. R., Mathuloe, P. T., \& Smit, B. W. (2009). An open economy New Keynesian DSGE model of the South African economy. South African Journal of Economics, 77(2), 207-227.

Svensson, L. E. (1997). Inflation forecast targeting: Implementing and monitoring inflation targets. European economic review, 41(6), 1111-1146.

Taylor, J. B. (1993). Discretion versus policy rules in practice. In Carnegie-Rochester conference series on public policy, North-Holland. 39, 195-214.

Woodford, M. (2003). Optimal interest-rate smoothing. The Review of Economic Studies, 70(4), 861-886.

Zeufack, A., Kopoin, A., Nganou, J. P., Tchana, F. T., \& Kemoe, L. (2016). Optimal allocation of natural resource surpluses in a dynamic macroeconomic framework: a DSGE analysis with evidence from Uganda. The World Bank. 